\title{
Enfekte total diz artroplastisine yaklaşım
}

\section{Management of infected total knee arthroplasty}

\author{
Ahmet Fırat, Osman Tecimel
}

Atatürk Eğitim ve Araştırma Hastanesi, Ortopedi ve Travmatoloji Kliniği, Ankara, Türkiye

\begin{abstract}
Çeşitli yayınlarda, total diz artroplastisi sonrası enfeksiyon insidansı \%0,5-2 arasında bildirilmiştir. Enfekte total diz artroplastisi ile başa çıkmanın tek yolu, ileriye dönük algoritmik bir yaklaşımdır. Total diz artroplastisi enfeksiyonları, genelde bakteriler aracılığıyla oluşur ve bunlar, sıklıkla ameliyat sırasında doğrudan veya hematojen yolla bulaşır. Konağın immün durumu, tedaviye yanıtı ve enfeksiyona yatkınlığı etkileyen en önemli faktördür. Total diz artroplastisi enfeksiyonu sınıflandırması, şikayetlerin süresine ve ameliyattan sonra geçen zamana bağlıdır. Enfeksiyona zamanında tanı konulması, kesinlikle kritik bir önem arz eder. Başvurularda en sık karşılaşılan şikayetler ve bulgular; ağrı, şişlik, ısı artışı ve sinovittir. Enfeksiyon tanısı için; sedimentasyon, C-reaktif protein (CRP), kan lökosit düzeyi, aspirasyon sıvısında hücre sayımı, gram boyama ve kültür, cerrahi sırasında dokuların incelenmesi gibi testlerin, tek tek değil kombine edilerek değerlendirilmesi son derece önemlidir.
\end{abstract}

Anahtar sözcükler: diz artroplastisi, total; enfeksiyon; tanı
The incidence of infection after total knee arthroplasty was reported as $0.5-2 \%$ in several series. The only way to overcome the infected total knee arthroplasty is having a prospective algorithmic approach. Total knee arthroplasty infections are usually caused by bacterial microorganisms and the contamination is via direct contact during surgery or haematogen dissemination. The immunologic condition of the host is the most important factor for tendency to infection and response to the therapy. The classification of the total knee arthroplasty infection is made according to the length of the symptomatic period and the elapsed time after the surgery. Early diagnosis of the infection is crucial. The most common symptoms are pain, swelling, warmth on the affected knee and findings of synovitis. For the diagnosis of the infection, sedimentation rate, C-reactive protein, blood count of the leukocytes, cell count on aspirated joint fluid, gram staining and culture of the aspirate and examination of the intraoperative tissues are evaluated in combination to get the best result.

Key words: knee arthroplasty, total; infection; diagnosis
T otal diz artroplastisi (TDA), gonartroz tedavisinde ağrının giderilmesi ve diz fonksiyonlarının düzeltilmesi açısından güvenilir ve tercih edilir bir tedavi yöntemi haline gelmiştir. ${ }^{[1]}$ Derin enfeksiyon, TDA'nın en kötü ve pahalı komplikasyonlarından birisidir. ${ }^{[2,3]}$ TDA sonrası enfeksiyon, çeşitli yayınlarda \%0,5-2 arasında değişen bir sıklığa sahip olmakla birlikte, bu oran, kronik steroid kullanımı, diabet ve immün yetmezlik gibi durumlarda artmaktadır. ${ }^{[4,5]}$ Enfekte TDA ile başa çıkmanın tek yolu, ileriye dönük algoritmik bir yaklaşımdır.

\section{TDA ENFEKSIYONU IÇiN RISK FAKTÖRLERi}

TDA enfeksiyonları, genelde bakteriler aracılığıyla oluşur ve bunlar sıklıkla ameliyat sırasında doğrudan veya hematojen yolla bulaşır. Ayrıca, fungal ve viral enfeksiyonlar da bildirilmiştir. ${ }^{[6]}$ Enfeksiyon gelişiminde, konakçı faktörleri önemli rol oynamaktadır. Dizdeki lokal sinoviyal dokunun enfeksiyondan korunmada etkili olduğu bildirilmesine rağmen, mekanizması tam olarak aydınlatılamamıştır. ${ }^{[7]}$

Bir TDA operasyonu esnasında kontaminasyon kaynaklarından en önemlisi, ameliyat odası ortamı ve burada da hastanın kendi cildidir. Kronik ülserler, diş abseleri, selülitler ve idrar yolu enfeksiyonları, TDA enfeksiyonu için mikroorganizma kaynağı olabilir.

Bakterinin biyofilm yapabilme karakteri de enfeksiyon tedavisini etkileyen önemli faktörlerdendir. Biyofilm tabaka, polisakkarid ve protein matriksten oluşur. Bu tabaka, immün sisteme ve antibiyotiklere

- Illetişim adresi: Doç. Dr. Ahmet Fırat, Atatürk EAH Ortopedi ve Travmatoloji Kliniği, Bilkent Yolu, Çankaya, Ankara Tel: 0312 - 2912525 e-posta: ahmetfirat24@yahoo.com

- Geliș tarihi: 8 Nisan 2015 Kabul tarihi: 8 Nisan 2015 
karşı bakteriyi korur. Yine bakteriler, genetik olarak antibiyotiklere karşı direnç mekanizmaları geliştirebilir. Dirençli mikroorganizmalarla enfekte olan TDA'ların tedavisi zordur.

\section{KONAK RISK FAKTÖRLERi}

Konağın immün durumu, tedaviye yanıtı ve enfeksiyona yatkınlığı etkileyen en önemli faktördür. İmmün yetmezlik; nötropeni ve hematolojik malignensiler nedeniyle oluşabileceği gibi, malnütrisyon, sigara kullanımı, diabet, ileri yaş gibi durumlarda da yetmezlikle sonuçlanabilir. Ayrıca, hastayı TDA ameliyatının riskleri hakkında bilgilendirirken, yine konakçıya ait risk faktörleri göz önüne alınmalıdır. ${ }^{[8]}$

Peersman ve arkadaşları, ${ }^{[9]} 6489$ TDA olgusunu inceledikleri çalışmalarında, enfeksiyon oranını \%0,39 olarak tespit etmişler, enfekte olguların primer TDA için tanısının, en sık osteoartrit (\%62), ikinci olarak romatoid artrit (\%20) ve üçüncü olarak da posttravmatik artrit (\%11) olduğunu bildirmişlerdir. Eşlik eden morbiditeler açısından, enfeksiyonun bazı durumlarla daha sıklıkla birliktelik gösterdiğini tespit etmişlerdir. Bunlar; geçirilmiş açık cerrahi, immünsupresif ilaç kullanımı, hipofosfatemi, beslenme bozukluğu, divertikülozis, başka bir yerdeki enfeksiyon, obezite, diabet, sigara, renal bozukluklar, hipotiroidizm ve alkol kullanımıdır. Yazarlar ayrıca, uzamış ameliyat süresinin de enfeksiyon gelişimi açısından risk faktörü olduğunu bildirmişler, en sık enfeksiyon ajanının Staphylococcus aureus (\%35) olduğunu tespit etmişlerdir. Bunlara ek olarak, 80 üzeri hasta yaşı, ameliyat öncesi dört günden fazla hastanede kalmak, dren kullanımı ve idrar yolu enfeksiyonları, risk faktörleri olarak bildirilmiştir. ${ }^{[10,11]}$ Ancak, idrar yolu enfeksiyonu ile TDA enfeksiyonu arasında ilişki olmadığını bildiren güncel yayınlar da mevcuttur. ${ }^{[12]}$ Literatürde, Staphylococcus aureus'un nasal dekolonizasyonunun, enfeksiyon için risk faktörü olduğu ve ameliyat öncesi dönemde saptanması halinde mupirocin ile tedavi edilmesi gerektiği bildirilmektedir.[13]

Protezin makroskopik olarak yeterli yumuşak doku kitlesi ile örtülmesi, kontaminasyonu azaltır. Geçirilmiş yumuşak doku yaralanmaları, kırıklar ve radyasyon maruziyeti, lokal dokuda değişiklikler oluşturarak risk oluşturabilir. Ayrıca, uzamış dren kullanımı ve yüksek kan INR (Uluslararası Düzeltme Oranı) düzeyi de enfeksiyon açısından risk oluşturmaktadır. ${ }^{[14]}$

\section{TDA ENFEKSIYONU SINIFLANDIRMASI}

TDA enfeksiyonu sınıflandırması, şikayetlerin süresine ve ameliyattan sonra geçen zamana bağlıdır. Mevcut tedavi seçenekleri bu görüşü destekler. TDA
Tablo 1. Enfekte TDA sınıflandırması

\begin{tabular}{ll}
\hline Sınıflandırma & Tanı \\
\hline Cerrahi esnasında pozitif kültür & $1<$ kültür pozitif hasta \\
Erken cerrahi sonrası enfeksiyon & $<4$ hafta \\
• Yüzeyel & • Kapsüle uzanmayan \\
• Derin & • Kapsüle uzanan \\
Akut hematojen enfeksiyon & $>4$ hafta \\
Geç kronik enfeksiyon & $>4$ hafta \\
\hline Tsukayama ve arkadaşları $(2003)^{[40]}$ &
\end{tabular}

enfeksiyonu sınıflamasında, üç ana kategori tanımlanmıştır (Tablo 1). ${ }^{[15,16]}$

Erken cerrahi sonrası enfeksiyonlar, TDA sonrası ilk dört hafta içinde meydana gelir. Bunlar, ameliyat esnasında veya hematojen olarak başlamış olabilir. Bu hastalarda aspirasyon, hematom ayırıcı tanısı yapmada en sık kullanılan tanısal girişimdir.

Önceden şikayeti olmayan ve fonksiyonları iyi olan, kısa süre önce gelişmiş akut şikayetleri olan hastalar$\mathrm{da}$, akut hematojen enfeksiyonlardan şüphelenilmelidir. Bu enfeksiyonlar, dental veya genitoüriner gibi girişimsel prosedürler sonrası veya herhangi bir abrazyon veya laserasyon sonrası gelişebilmekle beraber, sıklıkla kaynak saptanamamaktadır. Akut hematojen enfeksiyonlarda, eğer şikayetler dört hafta veya az süredir mevcut ise, özellikle bir haftadan az zamanda başlayanlarda açık debridman ve protezin korunması iyi sonuçlar verebilmektedir.

Dört haftadan uzun süredir şikayetleri olan hastalarda, geç kronik enfeksiyonlardan söz edilmektedir. Bu enfeksiyonlar, sıklıkla osteomiyelit, sinus ağzı ve protez gevşemesiyle ilişkilidir. Hastalar, sıklıkla sinsi bir ağrı, şişlik ve sertlik şikayetleriyle başvururlar. Bu hastaların, çoğu kez antibiyotik kullanma öyküleri mevcuttur. Bu durum, kültür duyarlılığını azaltmakta ve tanıyı güçleştirmektedir. ${ }^{[17]}$ Kronik enfeksiyonlar, dokulara penetre olmuş organizmalar içerir. Bu organizmalar, biyofilm tabakası oluşturarak operasyon dışı tedavilere direnç geliştirebilir. Dolayısıyla, bu enfeksiyonlarda tam eradikasyon için, hemen her zaman debridman, protezin çıkarılması ve en az 4-6 hafta antibiyotik tedavisi gerekir.

\section{TANI}

Enfeksiyona zamanında tanı konulması kesinlikle kritik bir önem arz eder. Hastanın ayrıntılı öyküsünün alınması ile enfeksiyon için ipuçları elde edilebilir. Akut 


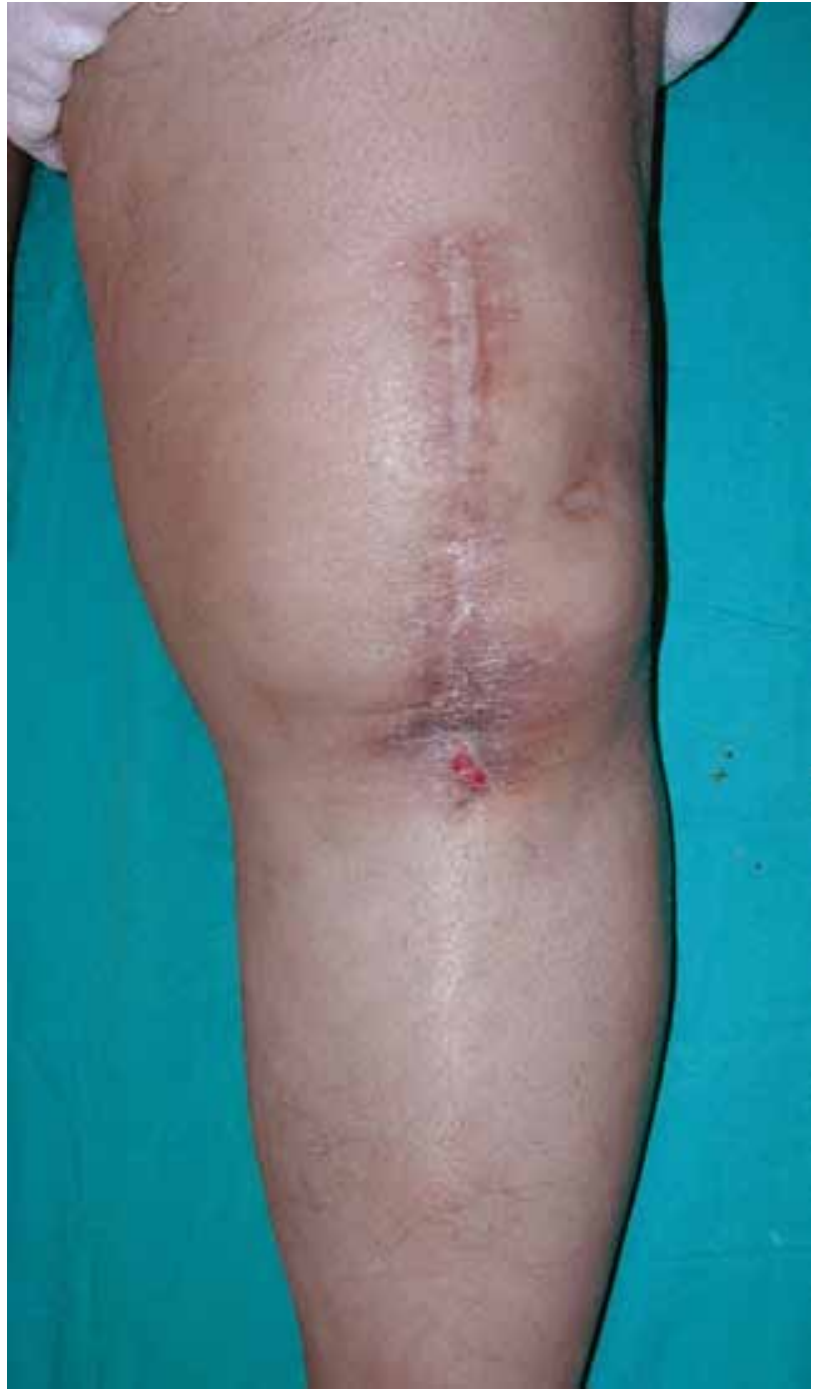

Şekil 1. Sinus ağzı mevcut olan bir hasta.

cerrahi sonrası dönemde hekim, gecikmiş yara iyileşmesi, devam eden rahatsızlık, hareket kısıtlılığı gibi durumlarda, hastanın enfekte olabileceğinden endişe duymalıdır. Ateş, titreme, üşüme ve döküntü, derin diz enfeksiyonunda sık olmamasına rağmen hekimde enfeksiyon şüphesi oluşturmalıdır. En çarpıcı enfeksiyon bulgularından ateş, titreme, sinüs ağzı ve pürülan akıntı, birçok enfekte TDA olgusunda maalesef görülmemektedir (Şekil 1). Başvurularda en sık karşılaşılan şikayetler ve bulgular; ağrı, şişlik, ısı artışı ve sinovittir. Hastalar, erken ameliyat sonrası dönemden itibaren, herhangi bir nedeni olmadan devam eden ağrı veya akut başlangıçı ağrı şikayeti ile başvurabilirler. Selülit, nadir bir başvuru nedenidir ve özellikle hematojen enfeksiyonları işaret eder. Ancak, selülitin yüzeyel mi yoksa derin bir enfeksiyonun uzantısı mı olduğunu ayırt etmek güçtür. Genel kural olarak, selülitli hastada diz hareketleri esnasında ağrı olmuyorsa, yüzeyel olduğu düşünülmelidir. Bu hastalarda eklem aspirasyonları, selülit olmayan alanlardan yapılmalıdır.

Ağrı şikayeti ile başvuran tüm TDA'lı hastalarda, basarak diz grafileri çekilmelidir. Akut cerrahi sonrası veya hematojenoz enfeksiyonlarda, akut gevşeme bulguları; kronik enfeksiyonlarda, özellikle osteomiyelit varlığında, endosteal erozyon, reaktif periosteal kemikleşme ve basende heterotopik ossifikasyon saptanabilir.

Enfeksiyon tanısı için; sedimentasyon, C-reaktif protein (CRP), kan lökosit düzeyi, aspirasyon sıvısında hücre sayımı, boyama ve kültür, cerrahi sırasında dokuların incelenmesi gibi testlerin, tek tek değil kombine edilerek değerlendirilmesi son derece önemlidir. ${ }^{[18,19]}$

Ağrılı TDA değerlendirmesinde birçok tanısal test tanımlanmıştır. Yaklaşık \%10-15 derin enfeksiyon olgusunda, standart cerrahi öncesi tanısal testlerle tanı konulamamaktadır. ${ }^{[18]}$ Kan beyaz küre ölçümü değerleri, bakteriyemi olmadığı sürece, derin enfeksiyonda genellikle yükselmez. ${ }^{[5]}$ Eritrosit sedimentasyon hızı, enfeksiyon için non-spesifik olup, ameliyat sonrası bir yıla kadar yüksek seyredebilir. ${ }^{[20,21]}$ Levitsky ve arkadaşları, eritrosit sedimentasyon hızının özgüllüğünü \%65 ve duyarlıı̆̆ını \%60 olarak bildirmişlerdir. ${ }^{[22]}$ C-reaktif protein (CRP), TDA sonrası 3-4 haftada normalleşme eğilimindedir. CRP'nin kalıcı olarak yüksek olması, enfeksiyona işaret edebilir. Spangehl ve arkadaşları, ${ }^{[19]}$ ağrılı TDA olgularında, tanısal olarak eritrosit sedimentasyon hızı ve CRP'nin her ikisinin pozitif olduğu durumlarda, \%83 oranında enfeksiyon saptamışlardır. Yine her iki testin negatif olduğu olgularda ise, enfeksiyonu \%100 ekarte etmişlerdir.

Ağrılı TDA değerlendirilmesinde, radyoizotop inceleme kullanılmaktadır. Teknesyum taraması, $\% 60$ duyarlılık ve \%65 oranında özgüllüğü nedeniyle, hastaların çoğunda efektif değildir. [22] İndium taraması, teknesyuma göre daha doğru sonuçlar vermektedir. Scher

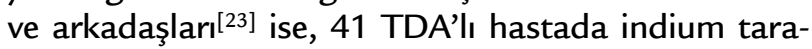
masının, duyarlılığını \%88 ve özgüllüğünü $\% 78$, pozitif öngörü değerini \%75, negatif öngörü değerini \%90 ve doğruluğunu \%83 olarak bildirmişlerdir. Bu çalışma, yüksek yüzdede yanlış pozitif indium taraması sonucunun, enfeksiyon değil gevşeme olduğunu göstermiştir.

Diz aspirasyonu, derin enfeksiyonun varlığını saptamada değerli bir yöntemdir. ${ }^{[24,25]}$ Aspire edilen sıvı hücre sayımı ve kültür için kullanılabilir. Klasik olarak her kübik milimetrede 25.000 'den fazla polimorfonükleer ağırıklı beyaz küre saptanması, büyük oranda enfeksiyonu göstermektedir. ${ }^{[25]}$ Bu testin duyarlılığı \%94-97, özgüllüğü \%88-98 oranlarında değişmektedir. Bununla beraber, son zamanlarda daha 
az beyaz küre sayısına sahip enfeksiyonlar da bildirilmektedir. ${ }^{[26,27]}$ Diz aspirasyonunun steril, özellikle laminer akımlı bir ortamda yapılması, yanlış sonuçların ortaya çıkmasını en aza indirecektir. Tekrarlayan aspirasyonlar ile, enfeksiyon ajanını tespit etme oranı arttırılacaktır. Aspirasyon yapılırken, anaerob ajanlar için de gerekli materyaller hazır bulundurulmalıdır. TDA enfeksiyonlarında en sık görülen ajanlar (\%65), aerobik gram-pozitif koklardır. Aerobik gram-negatif basiller daha az sıklıkta (\%6) saptanır. Anaerobik mikroorganizmalar, tüm ajanların yaklaşık \%4'ünü oluşturur. Ayrıca, literatürde brusella melitensis ve tüberküloz enfeksiyonları da bildirilmiştir. ${ }^{[28]}$

Enfeksiyon tanısının konulamadığı durumlarda, moleküler tanısal teknikler veya cerrahi sırasında frozen section histoanalizi kullanılabilir. Polimeraz zincir reaksiyonu (PCR), TDA sonrası sinoviyal sıvida bakteriyel patojeni saptamada kullanılabilir. ${ }^{[29]}$ Ancak, yüksek duyarlılığı olduğu için, maalesef yüksek oranda yanlış pozitif sonuç verir. ${ }^{[30]}$ Enfeksiyon varlığı açıkça saptanamayan çok sayıda hastada, histolojik analizler önemli rol oynamaktadır. Ameliyat esnasında örnek almak için, özellikle psödokapsül ve periprostetik membranda granülasyon dokusu içeren alanlar tercih edilmelidir. ${ }^{[31]}$ Yoğun fibröz veya fibrinden zengin dokuların genelde değeri yoktur. Bu dokulardaki hücresel olarak zengin beş alan, en az ikişer örnek alınarak incelenmelidir. ${ }^{[32,33]}$ Mirra kriterlerine göre, her yüksek yoğunluktaki alanda (high power field) 5 veya daha fazla nötrofil saptanması enfeksiyon olarak kabul edilir. ${ }^{[34]}$

Enfekte TDA tanısında, cerrahi sırasında alınan kültürün altın standart olduğunu bildiren çalışmalar olmasına rağmen, yanlış pozitif veya negatif sonuçlara yol açtığını bildiren çalışmalar da mevcuttur. ${ }^{[3,8,24]}$ Parvizi ve arkadaşları, ${ }^{[27]}$ sedimentasyon hızı, CRP ve aspirasyon sıvısında hücre sayımı ile, yüksek oranda tanıya ulaşılabileceğini bildirmişlerdir.

İnterlökin-6'nın (IL-6), enfekte TDA tanısı ve özellikle iki aşamalı revizyonda, reimplantasyon öncesinde enfeksiyon eradikasyonunu göstermede iyi bir marker olduğu bildirilmiştir. Ancak, literatürde IL-6 ile ilgili kanıt düzeyi yeterli değildir. ${ }^{[35]}$

TDA enfeksiyonu tanısında, tek başına yeterli olabilecek bir test yoktur. Tüm hastalardan dikkatli bir anamnez alınmalıdır. Sedimentasyon, CRP ve aspirasyon, birçok hasta için çok değerlidir. ${ }^{[27]}$ Diz aspirasyonu öncesinde iki hafta antibiyotiklerin kesilmesi önerilmesine rağmen, enfekte olduğu saptanan veya saptanamayan olgularda operasyon öncesi profilaktik antibiyotik kullanımının, cerrahi sırasında kültür sonuçlarını etkilemediği bildirilmiştir. ${ }^{[36]}$ Seri yapılan aspirasyonlar ile negatif kültür sonucu olan hastalarda, enfeksiyon ajanı tespit edilebilir. Şüpheli olgularda, tanı konulamazsa, cerrahi sırasında frozen section ile eklemin enfekte olup olmadığı saptanabilmektedir.

Günümüzde en sık kullanılan belirleyicilerin sedimentasyon ve CRP olmasına rağmen, birçok inflamatuvar olayda yükselmeleri nedeni ile, yeni biyobelirleyici arayışları sürmektedir. Serumda prokalsitonin, interlökin-6 (IL-6), tümör nekrozis faktör $\alpha$ (TNF- $\alpha$ ), short-chain exocellular lipoteichoic asid, soluble intercellular adhesion molecule-1 ve monocyte chemoattractant protein-1 gibi belirleyiciler, protez enfeksiyonu için daha özgül olabilir. Sinoviyal sıvida, IL-1 $\beta$, IL-6, IL-8, IL-17, TNF- $\alpha$, interferon- $\delta$ ve vasküler endoteliyal büyüme faktörü gibi sitokin ve belirleyicilerin yükseldiği gösterilmiştir. Daha özgül sinoviyal sıvı biyobelirleyicileri ise, sinoviyal CRP, $\alpha$-defensin, human $\beta$-defensin-2 (HBD-2) ve HBD-3, lökosit esteraz ve cathelicidin LL-37 olarak bildirilmiştir. Bu biyobelirleyiciler, protez enfeksiyonunun tanısında gelecekte etkin olabilir.

\section{KAYNAKLAR}

1. Insall JN, Hood RW, Flawn LB, Sullivan DJ. The total condylar knee prosthesis in gonarthrosis. A five to nine-year follow-up of the first one hundred consecutive replacements. J Bone Joint Surg Am 1983;65(5):619-28.

2. Cuckler JM, Star AM, Alavi A, Noto RB. Diagnosis and management of the infected total joint arthroplasty. Orthop Clin North Am 1991;22(3):523-30.

3. Rand JA, Fitzgerald RH Jr. Diagnosis and management of the infected total knee arthroplasty. Orthop Clin North Am 1989;20(2):201-10.

4. Segawa H, Tsukayama DT, Kyle RF, Becker DA, Gustilo RB. Infection after total knee arthroplasty. A retrospective study of the treatment of eighty-one infections. J Bone Joint Surg Am 1999;81(10):1434-45.

5. Windsor RE, Insall JN, Urs WK, Miller DV, Brause BD. Twostage reimplantation for the salvage of total knee arthroplasty complicated by infection. Further follow-up and refinement of indications. J Bone Joint Surg Am 1990;72(2):272-8.

6. Bezwada HP, Nazarian DG, Booth RE Jr. Haemophilus influenza infection complicating a total knee arthroplasty. Clin Orthop Relat Res 2002;(402):202-5.

7. Paulsen F, Pufe T, Conradi L, Varoga D, Tsokos M, Papendieck $\mathrm{J}$, Petersen W. Antimicrobial peptides are expressed and produced in healthy and inflamed human synovial membranes. J Pathol 2002;198(3):369-77.

8. Jämsen E, Huhtala H, Puolakka T, Moilanen T. Risk factors for infection after knee arthroplasty. A register-based analysis of 43,149 cases. J Bone Joint Surg Am 2009;91(1):38-47. CrossRef

9. Peersman G, Laskin R, Davis J, Peterson M. Infection in total knee replacement: a retrospective review of 6489 total knee replacements. Clin Orthop Relat Res 2001;(392):15-23.

10. Berbari EF, Hanssen AD, Duffy MC, Steckelberg JM, Ilstrup DM, Harmsen WS, Osmon DR. Risk factors for prosthetic joint infection: case-control study. Clin Infect Dis 1998;27(5):1247-54. 
11. Ridgeway S, Wilson J, Charlet A, Kafatos G, Pearson A, Coello R. Infection of the surgical site after arthroplasty of the hip. J Bone Joint Surg Br 2005;87(6):844-50.

12. Koulouvaris $P$, Sculco P, Finerty E, Sculco T, Sharrock NE. Relationship between perioperative urinary tract infection and deep infection after joint arthroplasty. Clin Orthop Relat Res 2009;467(7):1859-67. CrossRef

13. Hacek DM, Robb WJ, Paule SM, Kudrna JC, Stamos VP, Peterson LR. Staphylococcus aureus nasal decolonization in joint replacement surgery reduces infection. Clin Orthop Relat Res 2008;466(6):1349-55. CrossRef

14. Minnema B, Vearncombe M, Augustin A, Gollish J, Simor $A E$. Risk factors for surgical-site infection following primary total knee arthroplasty. Infect Control Hosp Epidemiol 2004;25(6):477-80.

15. McPherson EJ, Tontz W Jr, Patzakis M, Woodsome C, Holtom $P$, Norris $L$, Shufelt $C$. Outcome of infected total knee utilizing a staging system for prosthetic joint infection. Am J Orthop (Belle Mead NJ) 1999;28(3):161-5.

16. Tsukayama DT, Goldberg VM, Kyle R. Diagnosis and management of infection after total knee arthroplasty. J Bone Joint Surg Am 2003;85-A Suppl 1:S75-80.

17. Lonner JH, Beck TD Jr, Rees H, Roullet M, Lotke PA. Results of two-stage revision of the infected total knee arthroplasty. Am J Knee Surg 2001;14(1):65-7.

18. Austin MS, Ghanem E, Joshi A, Lindsay A, Parvizi J. A simple, cost-effective screening protocol to rule out periprosthetic infection. J Arthroplasty 2008;23(1):65-8. CrossRef

19. Spangehl MJ, Masri BA, O'Connell JX, Duncan CP. Prospective analysis of preoperative and intraoperative investigations for the diagnosis of infection at the sites of two hundred and two revision total hip arthroplasties. J Bone Joint Surg Am 1999;81(5):672-83.

20. Aalto $\mathrm{K}$, Osterman $\mathrm{K}$, Peltola $\mathrm{H}$, Räsänen J. Changes in erythrocyte sedimentation rate and C-reactive protein after total hip arthroplasty. Clin Orthop Relat Res 1984;(184):118-20.

21. Shih LY, Wu JJ, Yang DJ. Erythrocyte sedimentation rate and C-reactive protein values in patients with total hip arthroplasty. Clin Orthop Relat Res 1987;(225):238-46.

22. Levitsky KA, Hozack WJ, Balderston RA, Rothman RH, Gluckman SJ, Maslack MM, Booth RE Jr. Evaluation of the painful prosthetic joint. relative value of bone scan, sedimentation rate, and joint aspiration. J Arthroplasty 1991;6(3):237-44.

23. Scher DM, Pak K, Lonner JH, Finkel JE, Zuckerman JD, Di Cesare PE. The predictive value of indium-111 leukocyte scans in the diagnosis of infected total hip, knee, or resection arthroplasties. J Arthroplasty 2000;15(3):295-300.
24. Barrack RL, Harris WH. The value of aspiration of the hip joint before revision total hip arthroplasty. J Bone Joint Surg Am 1993;75(1):66-76.

25. Duff GP, Lachiewicz PF, Kelley SS. Aspiration of the knee joint before revision arthroplasty. Clin Orthop Relat Res 1996;(331):132-9.

26. Trampuz A, Hanssen AD, Osmon DR, Mandrekar J, Steckelberg JM, Patel R. Synovial fluid leukocyte count and differential for the diagnosis of prosthetic knee infection. Am J Med 2004;117(8):556-62.

27. ParviziJ, Ghanem E, Sharkey P, Aggarwal A, Burnett RS, Barrack RL. Diagnosis of infected total knee: findings of a multicenter database. Clin Orthop Relat Res 2008;466(11):2628-33. CrossRef

28. Nickinson RS, Board TN, Gambhir AK, Porter ML, Kay PR. The microbiology of the infected knee arthroplasty. Int Orthop 2010;34(4):505-10. CrossRef

29. Gallo J, Sauer P, Dendis M, Lovecková Y, Kolár M, Zapletalová $\mathrm{J}$, Janout V. Molecular diagnostics for the detection of prosthetic joint infection. Acta Chir Orthop Traumatol Cech 2006;73(2):85-91.

30. Mariani BD, Martin DS, Levine MJ, Booth RE Jr, Tuan RS. The Coventry Award. Polymerase chain reaction detection of bacterial infection in total knee arthroplasty. Clin Orthop Relat Res 1996;(331):11-22.

31. Bori G, Soriano A, García S, Gallart X, Mallofre C, Mensa J. Neutrophils in frozen section and type of microorganism isolated at the time of resection arthroplasty for the treatment of infection. Arch Orthop Trauma Surg 2009;129(5):591-5. CrossRef

32. Lonner JH, Desai P, Dicesare PE, Steiner G, Zuckerman JD. The reliability of analysis of intraoperative frozen sections for identifying active infection during revision hip or knee arthroplasty. J Bone Joint Surg Am 1996;78(10):1553-8.

33. Feldman DS, Lonner JH, Desai P, Zuckerman JD. The role of intraoperative frozen sections in revision total joint arthroplasty. J Bone Joint Surg Am 1995;77(12):1807-13.

34. Mirra JM, Amstutz HC, Matos M, Gold R. The pathology of the joint tissues and its clinical relevance in prosthesis failure. Clin Orthop Relat Res 1976:(117):221-40.

35. Hoell S, Borgers L, Gosheger G, Dieckmann R, Schulz D, Gerss J, Hardes J. Interleukin-6 in two-stage revision arthroplasty: what is the threshold value to exclude persistent infection before re-implanatation? Bone Joint J 2015;97-B(1):71-5. CrossRef

36. Burnett RS, Aggarwal A, Givens SA, McClure JT, Morgan PM, Barrack RL. Prophylactic antibiotics do not affect cultures in the treatment of an infected TKA. A prospective trial. Clin Orthop Relat Res 2010;468(1):127-34. CrossRef 